\title{
PENGARUH PROFITABILITAS, LIKUIDITAS, DAN RISIKO BISNIS PADA STRUKTUR MODAL PERUSAHAAN PROPERTI DAN REAL ESTATE DI BURSA EFEK INDONESIA
}

\author{
Mufidah $^{(1)}$ \\ I Gusti Ketut Agung Ulupui(2) \\ Rida Prihatni ${ }^{(3)}$ \\ (1),(2),(3)Fakultas Ekonomi, Universitas Negeri Jakarta \\ email:ulupui@yahoo.com
}

\begin{abstract}
ABSTRAK
Penelitian ini dilakukan untuk mendapatkan bukti empiris mengenai pengaruh profitabilitas, likuiditas, dan risiko bisnis terhadap struktur modal. Penelitian ini dilakukan sejak Juni 2017 dan menggunakan data sekunder yang didapatkan dari laporan keuangan perusahaan properti dan real estate sektor property, real estat dan konstruksi Bursa Efek Indonesia. Sampel yang digunakan pada penelitian ini adalah sebanyak 30 perusahaan selama tiga tahun, yaitu 2013-2015. Sampel didapatkan melalui teknik purposive sampling. Metode analisis yang digunakan adalah analisis statistik deskriptif, analisis uji asumsi klasik, dan analisis regresi linier berganda. Hasil penelitian ini adalah likuiditas berpengaruh negatif signifikan terhadap struktur modal, sedangkan profitabilitas dan risiko bisnis tidak berpengaruh signifikan terhadap struktur modal.
\end{abstract}

Kata Kunci: profitabilitas, likuiditas, risiko bisnis, struktur modal

ABSTRACT

This study was conducted to obtain empirical evidence on the influence of profitability, liquidity, and business risk on capital structure. This research was conducted since June 2017 and used secondary data obtained from annual reports of property and real estate companies in property, real estate and construction of Indonesia Stock Exchange. The sample used in this research is 30 companies for three years, namely $2013-$ 2015. The sample was obtained through purposive sampling technique.The analysis method used is descriptive statistical analysis, analysis of classical assumption test, and multiple linear regression analysis. The result of this research is liquidity has significant negative effect to capital structure, while profitability and business risk have no significant effect to capital structure.

Keywords: profitability, liquidity, business risk, capital structure

\section{PENDAHULUAN}

Keputusan pendanaan merupakan suatu keputusan yang harus diambil oleh manajer keuangan sebaik mungkin dalam kaitannya dengan kegiatan operasional perusahaan. Keputusan pendanaan suatu perusahaan yang baik dapat dilihat dari struktur modal, yaitu keputusan keuangan yang berkaitan dengan komposisi hutang, baik hutang jangka panjang dan hutang jangka pendek, saham preferen, dan saham biasa yang akan digunakan oleh perusahaan (Margaretha dan Ramadhan, 2010).

Struktur modal dalam sektor properti dan real estate, misalnya pembangunan apartemen yang dilakukan suatu perusahaan, dimana perusahaan yang menjual unit-unit apartemen meminta pembayaran uang muka sebesar $20 \%$ dari harga unit yang dilakukan oleh konsumen dengan rencana pembangunan pada awal Desember 2016 yang akan dimulai tahun 2017 dan akan diselesaikan pada pertengahan 2020. Jadi, perusahaan akan mendapatkan uang muka lebih dulu dari konsumen yang membeli unit apartemen.

Perusahaan dengan penjualan yang tinggi akan meningkatkan laba perusahaan sehingga dapat memperkuat struktur permodalan itu sendiri. Misalnya seperti yang terjadi pada perusahaan properti milik negara, PT PP Properti Tbk (PPRO) yang menyiapkan dana belanja modal sekitar Rp 1,5 triliun hingga Rp 2 triliun untuk membangun sejumlah proyek baru pada 2017.Belanja modal tersebut berasal dari dana internal sekitar 20-30 persen, dan sisanya dari setoran modal induk perusahaan sebesar $\mathrm{Rp} 1$ triliun, serta right issue sekitar $\mathrm{Rp}$ 500 miliar (Rinaldi, 2016). Dana dari hasil right issue akan digunakan untuk kegiatan bisnis perusahaan, seperti ekspansi dan mempertahankan tingkat pertumbuhan. tersebut membantu perusahaan mendapatkan dana tambahan yang nantinya akan 
digunakan untuk aset perusahaan. Sebaliknya, perusahaan dengan laba yang minim akan sulit menyelesaikan utang-utangnya sehingga akan menimbulkan kesenjangan komposisi dalam struktur modal karena pennggunaan utang terlalu banyak. Seperti yang terjadi pada PT Surayinti Permata Tbk (SIIP) yang di delisting oleh BEI dari daftar bursa. Terjadinya delisting terhadap PT Surayinti Permata disebabkan oleh masalah penyelesaian utang berlarut-larut (Munthe, 2012). BEI melakukan suspensi terhadap PT Suryainti Permata karena perusahaan gagal membayar bunga obligasi sebesar US $\$ 5,03$ juta kepada Oversign BV. Kasus tersebut salah satu contoh perusahaan bangkrut yang disebabkan manajemen keuangan tidak baik.

Peranan seorang manajer dalam keputusan pendanaan yang tepat, antara sumber dana dari modal sendiri maupun dana dari luar perusahaan sangat diperlukan untuk menentukan struktur modal yang optimal. Menurut (Brigham dan Houston, 2011) sasaran struktur modal akan memaksimalkan harga saham dalam suatu perusahaan.

Kemampuan suatu perusahaan untuk bisa menghasilkan laba menjadi bahan pertimbangan bagi para investor untuk berinvestasi dalam perusahaan tersebut karena pada hakikatnya seorang investor mengharapkan bisa mendapat return yang besar. Perusahaan dengan tingkat profitabilitas yang tinggi menghindarkan perusahaan dari kebangkrutan karena perusahaan tidak banyak menggunakan hutang melainkan menggunakan labanya dan memiliki kesempatan investasi yang lebih baik (Mikrawardhana, Hidayat, dan Azizah, 2015).

Likuiditas dalam suatu perusahaan menunjukkan kemampuan perusahaan untuk memenuhi setiap kewajiban jangka pendek yang dimiliki perusahaan. Menurut (Mikrawardhana, Hidayat, dan Azizah, 2015) bahwa pengaruh likuiditas dengan struktur modalnya positif akan mendorong investor untuk memberikan utang yang besar dikarenakan para investor merasa terjamin dengan adanya nilai aset perusahaan yang likuid.

Apabila kemampuan memenuhi kewajiban perusahaan baik, akan memberikan image kepada kreditur maupun investor bahwa perusahaan tersebut dapat mengurangi risiko terjadinya kebangkrutan sehingga investor dan kreditur tidak berpikir ulang untuk menanamkan modal ataupun memberikan pinjaman pada perusahaan. Sedangkan apabila variabilitas pendapatan tinggi, maka risiko bisnis perusahaan akan tinggi sehingga laba yang dihasilkan cenderung berfluktuasi yang berarti pendapatan tidak stabil, dengan adanya risiko bisnis yang tinggi perusahaan cenderung tidak mengurangi utang, tetapi tetap menggunakan utang dalam memenuhi kebutuhan dananya (Sawitri dan Lestari, 2015). Perusahaan yang menggunakan banyak utang dapat menyebabkan risiko bisnis meningkat. Semakin besar beban biaya yang harus dikeluarkan oleh perusahaan semakin besar pula risiko yang dihadapi perusahaan (Sawitri dan Lestari, 2015).

Teori pecking order merupakan salah satu dari sekian teori yang terkait dengan struktur modal perusahaan. Struktur modal merupakan perbandingan antara modal vs utang. Menurut (Hanafi, 2011) skenario urutan dalam teori Pecking order adalah pertama, perusahaan lebih memilih menggunakan pendanaan internal sebagai sumber pendanaannya. Dana internal tersebut diperoleh dari laba (keuntungan) yang dihasilkan dari kegiatan perusahaan. Perusahaan menghitung target rasio pembayaran didasarkan pada perkiraan kesempatan investasi. Kedua, perusahaan berusaha menghindari perubahan dividen yang tiba-tiba. Dengan kata lain, pembayaran dividen diusahakan konstan atau, kalau berubah terjadi secara gradual dan tidak berubah dengan signifikan. Ketiga, kebijakan dividen yang konstan (sticky) dengan fluktuasi keuntungan dan kesempatan investasi yang tidak dapat diprediksi, akan menyebabkan aliran kas yang diterima oleh perusahaan akan lebih besar dibandingkan dengan pengeluaran investasi pada saat-saat tertentu, dan akan lebih kecil pada saat yang lain. Keempat, jika pendanaan eksternal diperlukan, perusahaan akan mengeluarkan surat berharga yang paling aman terlebih dahulu.

Berdasarkan penjelasan tersebut dapat disimpulkan bahwa suatu perusahaan lebih memilih menggunakan pendanaan internal, namun jika pendanaan internal tidak mencukupi atau perusahaan harus menggunakan pendanaan eksternal, maka perusahaan akan mengeluarkan surat berharga yang paling aman terlebih dahulu, baru kemudian saham digunakan sebagai pilihan terakhir. Teori pecking order dalam (Hanafi, 2011) dapat menjelaskan kenapa perusahaan yang mempunyai tingkat keuntungan yang tinggi justru mempunyai tingkat utang yang lebih kecil. Tingkat utang yang kecil tersebut bukan dikarenakan perusahaan mempunyai target tingkat utang yang kecil, tetapi karena mereka 
tidak membutuhkan dana eksternal. Tingkat keuntungan yang tinggi menjadikan dana internal mereka cukup untuk memenuhi kebutuhan investasi.

Menurut (Keown, Martin, dan William, 2010) sasaran manajemen struktur modal adalah mencampur sumber dana permanen sedemikian rupa sehingga memaksimalkan harga saham biasa perusahaan. Atau sasaran ini bisa dipandang sebagai usaha mencari campuran dana yang meminimalkan biaya modal komposit perusahaan. Campuran sumber dana yang tepat dapat disebut sebagai struktur modal yang optimal. Menurut (Brigham dan Houston, 2011) apabila dalam rasio utang suatu perusahaan berada di bawah tingkat sasaran, maka perusahaan akan mengumpulkan modal dengan menerbitkan utang, sebaliknya jika rasio utang berada di bawah tingkat sasaran, ekuitaslah yang akan digunakan oleh perusahaan.

Struktur modal dalam suatu perusahaan terdiri atas beberapa komponen, diantaranya yaitu modal sendiri dan hutang. Modal sendiri adalah modal yang berasal dari perusahaan itu sendiri berupa cadangan dan laba, atau berasal dari pengambil bagian, peserta, atau pemilik (modal saham, modal peserta). Modal ini menjadi tanggungan terhadap keseluruhan risiko perusahaan dan secara yuridis modal ini merupakan jaminan bagi para kreditur (Riyanto, 2001).Dana yang berasal luar adalah modal yang berasal dari kreditur, dimana modal ini merupakan utang bagi perusahaan yang bersangkutan (Riyanto, 2001).

Rasio profitabilitas digunakan untuk mengukur kemampuan perusahaan menghasilkan keuntungan (profitabilitas) pada tingkat penjualan, aset, dan modal saham tertentu (Hanafi, 2011). Menurut (Jusuf, 2008) rasio profitabilitas adalah rasio yang menunjukkan kemampuan perusahaan mencetak laba. Untuk para pemegang saham (pemilik perusahaan), rasio ini menunjukkan tingkat penghasilan mereka dalam investasi.

Kasmir (2016) menyatakan, rasio profitabilitas merupakan rasio untuk menilai kemampuan dalam mencari keuntungan. Rasio ini juga memberikan ukuran tingkat efektivitas manajemen suatu perusahaan. Hal ini ditunjukkan oleh laba yang dihasilkan dari penjualan dan pendapatan investasi. Menurut (Samryn, 2013) rasio profitabilitas merupakan suatu model analisis yang berupa perbandingan data keuangan sehingga informasi keuangan tersebut menjadi lebih berarti.
Rasio likuiditas menurut (Brigham dan Houston, 2010) adalah rasio yang menunjukkan hubungan antara kas dan aset lancar perusahaan lainnya dengan kewajiban lancarnya. Menurut (Subramanyam dan Wild, 2011) mengemukakan bahwa likuiditas (liquidity) mengacu pada kemampuan perusahaan untuk memenuhi kewajiban jangka pendeknya. Makin tinggi jumlah aset lancar terhadap kewajiban lancar, makin besar keyakinan bahwa kewajiban lancar tersebut akan dibayar (Subramanyam dan Wild, 2011)

Bagi pemegang saham perusahaan, kurangnya likuiditas dapat meramalkan hilangnya kendali pemilik atau kerugian investasi modal. Saat pemilik perusahaan memiliki kewajiban tak terbatas, kurangnya likuiditas membahayakan aset pribadi mereka. Bagi kreditor perusahaan, kurangnya likuiditas dapat menyebabkan penundaan pembayaran bunga dan pokok pinjaman atau bahkan tidak dapat ditagih sama sekali. Pelanggan serta pemasok produk dan jasa perusahaan juga merasakan masalah likuidtas jangka pendek, antara lain ketidakmampuan perusahaan untuk memenuhi kontrak serta merusak hubungan dengan pelanggan dan pemasok penting.

Risiko bisnis menurut (Van Horne dan Wachowicz, 2007) merupakan ketidakpastian yang melekat atau bawaan (inherent) dalam operasi fisik perusahaan. Dampaknya terlihat dalam variabilitas laba operasional (EBIT) perusahaan atas perubahan dalam penjualan perusahaan. Risiko bisnis menurut Utomo (1999) merupakan risiko yang berhubungan dengan tidak stabilnya laba atau profit. Risiko bisnis menurut (Pertiwi dan Artini, 2014) merupakan risiko perusahaan saat tidak dapat menutupi biaya operasional dan dipengaruhi oleh stabilitas pendapatan dan biaya.

Risiko dapat meningkat ketika perusahaan menggunakan hutang yang tinggi untuk memenuhi kebutuhan pendanaannya. Risiko dapat timbul seiring dengan munculnya beban biaya atas pinjaman yang dilakukan perusahaan. Semakin besarnya beban biaya yang harus ditanggung oleh perusahaan, akan semakin besar juga risiko yang di hadapi (Sawitri dan Lestari, 2015). Menurut (Joni dan Lina, 2010) Risiko bisnis merupakan ketidakmampuan suatu perusahaan dalam memenuhi kebutuhan dananya untuk kegiatan operasi yang merupakan salah satu risiko yang dihadapi perusahaan ketika menjalankan operasinya. Risiko bisnis menurut (Brigham dan 
Houston, 2011) adalah tingkat risiko inheren dalam operasi perusahaan jika tidak menggunakan hutang.

Perusahaan yang menghasilkan laba yang tinggi dapat memenuhi kebutuhan pendanaannya dengan laba tersebut sehingga akan meminimalisir penggunaan hutang. Dalam penelitian yang dilakukan oleh (Pertiwi dan Artini, 2014) tentang pengaruh risiko bisnis, profitabilitas dan keputusan investasi terhadap struktur modal menyatakan bahwa profitabilitas berpengaruh terhadap struktur modal. Hasil penelitian tersebut diperkuat dengan penelitian (Bhawa dan Dewi, 2015) yang menyatakan bahwa rasio profitabilitas berpengaruh terhadap struktur modal. Hasil ini menyatakan bahwa jika semakin besar profitabilitas maka struktur modal semakin kecil dan sebaliknya jika semakin kecil profitabilitas maka struktur modal semakin besar pula. Dengan kata lain, apabila profitabilitas tinggi, perusahaan akan mempunyai dana internal yang lebih besar. Semakin tinggi profitabilitas perusahaan akan menandakan laba perusahaan juga tinggi. Jika perusahaan labanya tinggi maka perusahaan akan lebih sedikit memerlukan hutang. Dengan demikian hipotesis yang akan diuji adalah:

$\mathrm{H}_{1}$ : profitabilitas berpengaruh terhadap struktur modal.

Aktiva lancar yang tinggi dibutuhkan dalam suatu perusahaan. Perusahaan yang memiliki lebih banyak aktiva yang likuid menunjukkan bahwa perusahaan tersebut mempunyai kemampuan lebih besar untuk memnuhi kewajiban yang jatuh tempo (Keown dan Martin, 2008). Dalam penelitian yang dilakukan oleh (Mikrawardhana, Hidayat, dan Azizah, 2015) tentang pengaruh profitabilitas dan likuiditas terhadap struktur modal menyatakan bahwa likuiditas berpengaruh signifikan terhadap struktur modal. Hasil penelitian tersebut didukung oleh penelitian yang dilakukan oleh (Bhawa dan Dewi, 2015) yang menyatakan hasil bahwa likuiditas berpengaruh terhadap struktur modal, dimana jika semakin besar likuiditas maka semakin besar pula struktur modal dan jika semakin kecil likuiditas maka semakin kecil pula struktur modal. Semakin tinggi kemampuan perusahaan dalam mengembalikan kewajiban- kewajiban jangka pendeknya maka semakin likuid perusahaan tersebut sehingga kepercayaan dari kreditur meningkat dan mempermudah perusahaan memperoleh utang jangka panjangnya. Dengan demikian hipotesis yang akan diuji adalah:
$\mathrm{H}_{2}$ : likuiditas berpengaruh terhadap struktur modal.

Ketidakmampuan suatu perusahaan dalam memenuhi kebutuhan dananya untuk kegiatan operasi yang merupakan salah satu risiko yang dihadapi perusahaan ketika menjalankan operasinya (Joni dan Lina, 2010). Mohammed (2012) juga menyatakan bahwa risiko bisnis berpengaruh positif terhadap struktur modal. Pernyataaan tersebut juga didukung penelitian Pertiwi dan Artini, (2014) menyatakan hasil bahwa risiko bisnis berpengaruh terhadap struktur modal, menunjukkan bahwa semakin tinggi risiko bisnis suatu perusahaan, semakin tinggi rasio utangnya.

Apabila variabilitas pendapatan tinggi, maka risiko bisnis perusahaan akan tinggi sehingga laba yang dihasilkan cenderung berfluktuasi yang berarti pendapatan tidak stabil, dengan adanya risiko bisnis yang tinggi perusahaan cenderung tidak mengurangi utang, tetapi tetap menggunakan utang dalam memenuhi kebutuhan dananya (Sawitri dan Lestari, 2015). Dalam penelitian yang dilakukan oleh (Wiagustini dan Pertamawati, 2015) menyatakan bahwa dengan meningkatnya risiko bisnis dalam suatu perusahaan, maka penggunaan hutang jangka panjang perusahaan juga akan ikut meningkat. Hipotesis yang diajukan adalah:

$\mathrm{H}_{3}$ : risiko bisnis berpengaruh terhadap struktur modal.

\section{METODE PENELITIAN}

Penelitian ini menggunakan metode kuantitatif berupa analisis pengaruh rasio keuangan dalam menelitistruktur modal di perusahaan properti dan real estat. Populasi yang digunakan dalam penelitian ini adalah perusahaan properti dan real estat sektor property, real estat dan konstruksi tahun 2013-2015. Variabel independen yang digunakan dalam penelitian ini adalah struktur modal. Variabel struktur modal ini diproksi dengan rasio total utang terhadap ekuitas. Variabel independen dalam penelitian ini adalah profitabilitas yang diproksikan dengan rasio margin laba bersih atau Net Profit Margin (NPM), Variabel likuiditas yang diproksikan dengan rasio lancar yang menunjukkan seberapa banyak aktiva lancar yang tersedia untuk menutupi kewajiban jangka pendek yang segera jatuh tempo (Kasmir, 2016), Variabel risiko bisnis diproksikan dengan degree of operating leverage (DOL) yaitu persentase perubahan dalam laba operasional atas perubahan persentase dalam output (penjualan) (Van Horne dan Wachowicz, 2007). Data sekunder yang 
digunakan dalam penelitian ini adalah laporan keuangan yang telah terdaftar dan di audit di website Bursa Efek Indonesia yaitu http://idx.co.id.Teknik pengambilan sampel dalam penelitian ini digunakan purposive sampling. Kriteria dalam pemilihan sampel ini adalah 1) Perusahaan properti dan real estate yang terdaftar di Bursa Efek Indonesia tahun 2013-2015 secara konsisten; 2) Menerbitkan laporan keuangan secara lengkap selama tahun 2013-2015; 3) Perusahaan yang memiliki laba positif secara konsisten selama tahun penelitian.

\section{HASIL DAN PEMBAHASAN}

Berdasarkan kriteria-kriteria sampel diatas, maka jumlah perusahaan yang bisa dijadikan sampel dalam penelitian ini adalah 30 sampel dengan tahun pengematan selama 3 tahun sehingga jumlah observasi sebesar 60. Sebelum dilakukan uji hipotesis dengan menggunakan regresi linear berganda maka terlebih dahulu dilakukan uji asumsi mklasik yang memberikan hasil bahwa hasil uji normalitas menunjukkan bahwa data terdistribusi normal, uji multikolinearitas menunjukkan bahwa variabel independen di dalam model regresi tidak mempunyai masalah multikolinearitas, hasil dari uji autokorelasi yang menunjukkan bahwa data dalam penelitian tidak terdapat autokorelasi, uji heteroskedastisitas dengan uji glejser bahwa model regresi pada penelitian ini terbebas dari heteroskedastisitas. Dengan metode regeresi linier berganda maka hasilnya.

Tabel 1. Hasil Uji Hipotesis dengan Regresi Linier Berganda

\begin{tabular}{|c|c|c|c|c|c|}
\hline \multicolumn{6}{|c|}{ Coefficients $^{\text {a }}$} \\
\hline \multirow[t]{2}{*}{ Model } & \multicolumn{2}{|c|}{$\begin{array}{l}\text { Unstandardized } \\
\text { Coefficients }\end{array}$} & \multirow{2}{*}{$\begin{array}{c}\text { Standardized } \\
\text { Coefficients } \\
\text { Beta }\end{array}$} & \multirow[t]{2}{*}{$\mathrm{t}$} & \multirow[t]{2}{*}{ Sig. } \\
\hline & $\mathrm{B}$ & Std. Error & & & \\
\hline (Constant) & 1,116 & 0,119 & & 9,414 & 0,000 \\
\hline NPM & $-0,337$ & 0,235 & $-0,151$ & 1,438 & 0,154 \\
\hline RL & $-0,082$ & 0,037 & $-0,230$ & 2,215 & 0,029 \\
\hline DOL & $-0,015$ & 0,014 & $-0,111$ & 1,051 & 0,296 \\
\hline
\end{tabular}

Variabel dependen: DER

Sumber: hasil pengolahan data

Berdasarkan Tabel 1, maka model persamaan regresi dari penelitian ini adalah:

$\mathrm{DER}=1,116-0,337 \mathrm{NPM}-0,082 \mathrm{RL}-0,015 \mathrm{DOL}+\varepsilon$ Keterangan:

$\begin{array}{ll}\text { DER } & \text { : Struktur Modal } \\ \text { NPM } & : \text { Profitabilitas } \\ \text { RL } & : \text { Likuiditas } \\ \text { DOL } & : \text { Risiko Bisnis }\end{array}$

\section{Uji Hipotesis}

Hasil uji hipotesis pertama menunjukkan bahwa profitabilitas tidak berpengaruh terhadap struktur modal dibuktikan dengan nilai signifikansi lebih besar dari tingkat signifikansi 0,05 yaitu 0,154 . Hasil uji hipotesis kedua menunjukkan bahwa likuiditas berpengaruh negatif signifikan terhadap struktur modal dibuktikan nilai siqnifikansi sebesar 0,029 lebih kecil dari tingkat signifikansi 0,05 . Hasil uji hipotesis ketiga menunjukkan bahwa risiko bisnis tidak berpengaruh terhadap struktur modal dibuktikan dengan nilai signifikansi pada risiko bisnis sebesar 0,296, dimana angka ini lebih besar dari signifikansi 0,05

Hasil uji koefisien determinasi menunjukkan nilai $\mathrm{R}^{2}$ adalah 0,061 . Hal ini berarti sebesar 6,1 persen variabel dependen, struktur modal, dapat dijelaskan oleh ketiga variabel independen yang masuk dalam model regresi yaitu profitabilitas, likuiditas, dan risiko bisnis. Sedangkan sisanya yaitu sebesar 93,1 persen dapat dijelaskan oleh variabel-variabel independen lainnya. Pembahasan terhadap hasil pengujian statistik yang telah dilakukan adalah sebagai berikut:

\section{Pengaruh profitabilitas terhadap struktur modal}

Berdasarkan hasil uji yang dilakukan pada variabel profitabilitas terhadap variabel struktur modal menunjukkan bahwa variabel profitabilitas tidak memiliki pengaruh terhadap struktur modal. Hasil penelitian ini sejalan dengan penelitian yang dilakukan oleh (Kurniawan, 2013) mengatakan pertumbuhan pendapatan tidak mencukupi untuk melakukan pembelian aset perusahaan, sehingga perusahaan perlu menggunakan pendanaan eksternal untuk melakukan pembelian aset perusahaan. (Oktaviani dan Malelak, 2014) mengatakan orientasi dari profitabilitas di periode sebelumnya memungkinkan pihak manajemen perusahaan menganggap tidak mempengaruhi keputusan struktur modal perusahaan yang disebabkan oleh harga bahan baku properti yang naik menyebabkan profitabilitas perusahaan menurun. 
Profitabilitas yang tidak berpengaruh terhadap struktur modal disebabkan oleh beberapa hal. Penjualan yang menurun menyebabkan perusahaan mengalami penurunan pendapatan. Penurunan penjualan tersebut disebabkan turunnya permintaan akibat daya beli masyarakat menurun. Perlambatan ekonomi yang hanya berkisar 4-4,5 persen, nilai tukar rupiah terhadap dollar AS yang sempat mencapai angka $\mathrm{Rp} 13.400$, peraturan baru yang dikeluarkan oleh Bank Indonesia, serta harga bahan bakar minyak yang naik menjadi faktor utama sektor properti mengalami penurunan penjualan (Alexander, 2015). Dengan adanya faktor-faktor tersebut mengakibatkan terjadinya kenaikan bahan baku properti yang memberikan dampak profitabilitas perusahaan menjadi menurun. Dalam bisnisnya, perusahaan properti menggunakan sistem pre-order dimana pada periode tertentu perusahaan akan mempromosikan proyek untuk menarik minat masyarakat yang menyebabkan perusahaan tidak terlalu bergantung pada sumber pendanaan utang atau ekuitas (Oktaviani dan Malelak, 2014). Selain itu, perusahaan properti dan real estate dalam usahanya memerlukan lahan untuk membangun produknya, dimana lahan yang murah banyak dicari oleh para pengembang. Dalam UU No.1 tahun 2011 serta UU No.2 tahun 2011 menyebutkan bahwa pengembang harus menyelesaikan 20 persen pembangunan sebelum properti tersebut bisa dijual. Sehingga perusahaan membutuhkan modal yang besar untuk bisa melakukan pembangunan tersebut dengan menggunakan tambahan modal diluar sumber dana internal yang dimiliki perusahaan karena jika hanya mengandalkan sumber pendanaan internal saja tidak akan mencukupi (Kurniawan, 2013).

Hasil ini tidak sesuai dengan teori pecking order yang menyatakan bahwa perusahaan lebih memilih menggunakan pendanaan internal sebagai sumber pendanaannya, jika pendanaan eksternal dibutuhkan perusahaan akan mengeluarkan surat berharga lebih dulu, karena adanya perlambatan ekonomi yang menyebabkan profitabilitas perusahaan menurun serta adanya sistem pre-order sehingga tidak terlalu bergantung dengan sumber pendanaan utang atau ekuitas.

\section{Pengaruh likuiditas terhadap struktur modal}

Berdasarkan hasil uji yang dilakukan pada variabel likuiditas terhadap variabel struktur modal menunjukkan bahwa variabel likuiditas memiliki pengaruh negatif signifikan terhadap struktur modal.
Hasil ini sejalan dengan penelitian terdahulu yang menyatakan bahwa likuiditas memiliki pengaruh terhadap struktur modal, yaitu hasil penelitian (Widayanti, Triaryati, dan Abundanti, 2016) mengatakan bahwa likuiditas bepengaruh negatif signifikan terhadap struktur modal. Likuiditas yang semakin tinggi akan menurunkan struktur modal perusahaan yang berarti perusahaan dengan likuiditas tinggi memiliki kemampuan membayar utang jangka pendeknya yang cenderung menurunkan utang sehingga struktur modal menjadi lebih kecil. Pada penelitian (Primantara dan Dewi, 2016) mengatakan bahwa likuiditas berpengaruh terhadap struktur modal. Perusahaan dengan likuiditas yang semakin tinggi maka kemampuannya dalam membayar kewajiban jangka pendek semakin besar. Berdasarkan teori pecking order perusahaan akan lebih memilih menggunakan pendanaan internal sebagai sumber pendanaannya, jika pendanaan eksternal dibutuhkan perusahaan akan mengeluarkan surat berharga lebih dulu.

Perusahaan dengan likuiditas yang tinggi, memiliki aset lancar yang tinggi untuk membiayai aktivitas perusahaan. Dengan menggunakan aset lancar yang dimiliki perusahaan dapat memenuhi kewajiban-kewajiban jangka pendeknya, maka perusahaan dengan tingkat likuiditas tinggi semakin kecil penggunaan utang yang berarti semakin kecil struktur modalnya (Hardianti dan Barbara, 2010). Sehingga perusahaan dengan tingkat likuiditas tinggi cenderung menggunakan utang yang relatif rendah dikarenakan aset lancar perusahaan yang mampu menutupi kebutuhan dana yang dibutuhkan oleh perusahaan. Oleh karena itu, semakin besar tingkat likuiditas, akan semakin kecil struktur modal perusahaan karena perusahaan akan menggunakan dana internal lebih dulu daripada menggunakan utang.

\section{Pengaruh risiko bisnis terhadap struktur modal}

Berdasarkan hasil uji yang dilakukan pada variabel risiko bisnis terhadap variabel struktur modal menunjukkan bahwa variabel risiko bisnis tidak berpengaruh terhadap struktur modal. Penelitian ini sejalan dengan penelitian terdahulu yang menyatakan bahwa risiko bisnis tidak memiliki pengaruh terhadap struktur modal. Pada penelitian (Joni dan Lina, 2010), (Hardianti dan Barbara, 2010), (Firnanti, 2011) yang mengatakan bahwa risiko bisnis tidak memiliki pengaruh terhadap struktur modal. Kemudian pada penelitian (Bhawa dan Dewi, 2015) dan (Sawitri dan Lestari, 2015) juga menyatakan 
bahwa risiko bisnis berpengaruh positif tidak signifikan terhadap struktur modal.

Hasil penelitian ini mengindikasikan belum tentu perusahaan yang memiliki risiko tinggi lebih memilih menggunakan pendanaan internal dibandingkan dengan menggunakan pendanaan eksternal berupa utang, begitu pula sebaliknya dengan suatu perusahaan yang memiliki risiko rendah belum tentu akan lebih memilih menggunakan pendanaan dari luar untuk membiayai investasi maupun mengembangkan usaha perusahaan (Hardianti dan Barbara, 2010). Hal tersebut harus disesuaikan dengan kondisi perusahaan untuk menentukan keputusan mana yang akan diambil perusahaan dalam menggunakan pendanaanya untuk kegiatan tersebut, misalnya perusahaan yang memiliki risiko bisnis tinggi namun memiliki reputasi kinerja yang baik, perusahaan tetap dapat menggunakan pendanaan eksternal karena adanya kepercayaan dari kreditor atas reputasi kinerja yang baik tersebut.

Keseimbangan antara pendanaan dari luar dengan pendanaan internal lebih disukai oleh perusahaan untuk mengindari terjadinya kegagalan bisnis perusahaan sehingga tidak hanya mengandalkan satu sumber pendanaan saja. Walaupun suatu risiko bisnis yang besar dapat membawa pada gagalnya bisnis perusahaan, tetapi tingkat risiko tinggi dapat memungkinkan kreditor untuk meminta tingkat pengembalian yang lebih tinggi (Firnanti, 2011). Selain itu, kreditor dapat mengandalkan aset tetap dalam perusahaan untuk digunakan sebagai jaminan dari pendanaan atau pinjaman yang di berikan. Oleh karena itu, tingkat risiko bisnis dalam suatu perusahaan tidak dapat memperlihatkan sumber pendanaan yang akan dipilih oleh perusahaan dengan pasti.

\section{SIMPULAN DAN SARAN}

Berdasarkan pembahasan sebelumnya, maka dapat dibuat kesimpulan adalah 1) Profitabilitas tidak mermiliki pengaruh signifikan terhadap struktur modal. Hal ini dikarenakan adanya perlambatan ekonomi yang terjadi di indonesia yang hanya berkisar 4-4,5 persen menyebabkan profitabilitas perusahaan menurun; 2) Likuiditas berpengaruh negatif signifikan terhadap struktur modal. Hal ini dapat terjadi karena perusahaan dengan tingkat likuiditas tinggi cenderung menggunakan utang relatif rendah dikarenakan aset lancar perusahaan yang mampu menutupi kebutuhan dana yang dibutuhkan oleh perusahaan; 3) Risiko bisnis tidak memiliki pengaruh signifikan terhadap struktur modal. Hal ini dapat terjadi karena tingkat risiko bisnis suatu perusahaan tidak dapat memperlihatkan secara pasti sumber pendanaan yang akan dipilih oleh perusahaan.

\section{REFERENSI}

Alexander, H. B. 2015. Sektor Properti Makin Terpuruk. Dipetik November 18, 2017, dari kompas. com:http://www.kompas.com/properti/ $\mathrm{read} / 2015 / 06 / 12 / 083219221 / \mathrm{sektor}$.properti. makin.terpuruk.

Assegaf, A. 2014. Pengaruh Profitabilitas, Ukuran Perusahaan, Peluang Pertumbuhan Perusahaan, Struktur Aktiva, Risiko Bisnis dan Nondebt Tax Shield Terhadap Struktur Modal Perusahaan Food and Beverage yang Terdaftar di Bursa Efek Indonesia Periode 2010-2013. Jurnal Ilmiah Mahasiswa FEB, Vol. 3 (1).

Astuti, R. A., Ritonga, K. dan Al Azhar, A. 2014. Pengaruh Pertumbuhan Aset, Profitabilitas, dan Pertumbuhan Penjualan Terhadap Struktur Modal Pada Perusahaan Real Estate Dan Properti Yang Terdaftar Di Bursa Efek Indonesia Periode 2010-2012. Jurnal Online Mahasiswa Bidang Ilmu Ekonomi, 1(2).

Bhawa, I. B. dan Dewi, M. R. 2015. Pengaruh Ukuran Perusahaan, Likuiditas, Profitabilitas, Dan Risiko Bisnis Terhadap Struktur Modal Perusahaan Farmasi. E-Jurnal Manajemen Unud, 4 (7). pp.1949-1966.

Brigham, E. F. dan Houston, J. F. 2010. Dasardasar Manajemen Keuangan. Jilid 1. Jakarta: Salemba Empat.

Brigham, E. F. dan Houston, J. F. 2011. Dasar-dasar Manajemen Keuangan. Jilid 2. Jakarta: Salemba Empat.

Caesario, E. B. 2017. PPRO akan Bagikan Dividen Rp73 Miliar. Dipetik Mei 16, 2017, dari bisnis.com: http://m.bisnis.com/market/read/ 20170308/192/635181/ppro-akan-bagikandividen-rp-73-miliar

Dimitri, M. dan Sumani. 2013. Analisis Pengaruh Likuiditas, Profitabilitas, Ukuran, Usia dan Pertumbuhan Perusahaan Terhadap Struktur Modal. Jurnal Manajemen, 1(1).

Firnanti, F. 2011. Faktor-faktor yang Mempengaruhi Struktur Modal Perusahaan Manufaktur di Bursa Efek Indonesia. Jurnal Bisnis Dan Akuntansi, 13(2), pp.119-128. 
Ghozali, H. I. dan Ratmono, D. 2013. Analisis Multivariat dan Ekonometrika: Teori, Konsep, dan Aplikasi dengan Eviews 8. Semarang: Badan Penerbit Universitas Diponegoro.

Ghozali, I. 2016. Aplikasi Analisis Multivariate dengan program IBM SPSS 23. Semarang: Badan Penerbit Universitas Diponegoro.

Godfrey, J. dan all, E. 2010. Accounting Theory. Milton: John Wiley \& Sons Australia, Ltd.

Gujarati, D. 2003. Ekonometrika Dasar. Jakarta: Erlangga.

Gunawan, A. 2011. Pengaruh Profitabilitas dan Perputaran Aktiva Terhadap Struktur Modal. Jurnal Manajemen dan Bisnis, 11(1).

Hadi, F. 2014, Warta Kota. Dipetik November 30, 2017, dari Warta Kota Website: wartakota. tribunnews.com/2014/11/24/pertumbuhanproperti-diperkirakan-hanya-10-persen-ditahun-2015

Hadianto, B. dan Tayana, C. 2010. Pengaruh Risiko Sistematik, Struktur Aktiva, Profitabilitas dan Jenis Perusahaan Terhadap Struktur Modal Emiten Sektor Pertambangan: Pengujian Hipotesis Trade-Off. Jurnal Akuntansi 2(1).pp. 15-39

Hanafi, M. M. 2011. Manajemen Keuangan. Yogyakarta: BPFE-Yogyakarta.

Hardianti, S. dan Barbara, G. 2010. Pengaruh Size, Likuiditas, Profitabilitas, Risiko, dan Pertumbuhan Penjualan Terhadap Struktur Modal . Jurnal Akuntansi dan Investasi, 11(2), pp. 148-165.

Hermanto, B. dan Agung, M. 2015. Analisa Laporan Keuangan. Jakarta: Lentera Printing.

Horne, J. C., dan Wachowicz, J. J. 2012. PrinsipPrinsip Manajemen Keuangan (Fundamentals of Financial Management). Jakarta: Salemba Empat.

Insiroh, L. 2014. Pengaruh Profitabilitas, Ukuran Perusahaan, Pertumbuhan Aset, dan Struktur Aset Terhadap Struktur Modal. Jurnal Ilmu Manajemen, 2(3).

Irham, F. 2012. Pengantar Manajemen Keuangan: Teori dan Soal Jawab. Bandung: Alfabeta.

Jonathan. 2016. Koranesia.Com. diakses Tanggal 15 Juni 2017

Julita. 2007. Pengaruh Net Profit Margin dan Return On Investment Terhadap Struktur Modal Pada Perusahaan Asuransi yang Terdaftar di Busa Efek Indonesa. Jurnal Kultura, 8(1).
Junita, M. Nasir, A., \& Ilham, E. 2014. Pengaruh Profitabilitas, Pertumbuhan Aset, Operating Leverage, dan Ukuran Perusahaan Terhadap Struktur Modal Studi Empiris Pada Perusahaan Food and Beverages yang Terdaftar di Bursa Efek Indonesia periode 2010-2012. Jurnal Online Mahasiswa Bidang Ilmu Ekonomi, $1(2)$.

Jusuf, J. 2008. Analisis Kredit untuk Account Officer. Jakarta: PT Gramedia Pustaka Utama.

Kasmir, D. 2016. Analisis Laporan Keuangan. Jakarta: PT. Raja Grafindo Persada.

Keown dan Martin, J. D. 2008. Manajemen Keuangan: Prinsip dan Penerapan, Jilid 1. Jakarta: Indeks.

Keown, A. Martin, J., \& William, P. 2010. Manajemen Keuangan: Prinsip dan Penerapan. Jilid 2. Jakarta: PT Indeks.

Krsitian, N. \& Khuzaini. 2014. Pengaruh Likuiditas Dan Profitabilitas Terhadap Struktur Modal Dan Rasio Aktivitas Sebagai Intervening.

Kuncoro, M. 2009. Metode Riset untuk Bisnis \& Ekonomi. Jakarta: Erlangga.

Kurniawan, Z. 2013. Pengaruh Prospek Perusahaan, Profitabilitas, Ukuran Perusahaan, dan Aset Tetap Berwujud Terhadap Struktur Modal . Jurnal Ilmiah Mahasiswa FEB, vol 2, no 1.

Kusuma, G. I. Suhadak, \& Zainul, A. 2013. Analisis Pengaruh Profitabilitas dan Tingkat Pertumbuhan Terhadap Struktur Modal dan Nilai Perusahaan. Jurnal Administrasi Bisnis, 7(2).

Margaretha, F. \& Ramadhan, A. R. 2010. faktorfaktor yang mempengaruhi struktur modal pada industri manufaktur di BEI.Jurnal Bisnis dan Akuntansi. 12(2).pp. 119-130

Mikrawardhana, M. R., Hidayat, R. R., \& Azizah, D. F. 2015. Pengaruh Profitabilitas dan Likuiditas Terhadap Struktur Modal Perusahaan Multinasional (Studi pada Perusahaan Multinasional Yang Terdaftar di Bursa Efek Indonesia Tahun 2010-2013). Jurnal Admisitrasi Bisnis (JABI), 8(2). pp.1-7

Mohammed.,D.2012. Impact of business risk on corporate capital structure of publicly - listed nigerian companies. IOSR Joural of Business and Management, 5 (2): 34-46

Munawir. 2007. Analisa Laporan Keuangan. Yogyakarta: Liberty Yogyakarta.

Munthe, B. C. 2012. Mulai besok, SIIP resmi delisting dari bursa. Dipetik Juli 19, 2017, dari 
kontan.co.id: m.kontan.co.id/news/mulai-besoksiip-resmi-delisting-dari-bursa

Nabhani, A. 2011, BEI Suspensi Perdagangan PWSI karena Bangkrut. Dipetik Juli 19, 2017, dari neraca.co.id: www.neraca.co.id

Naibaho, A., Topowijono, \& Azizah, D. F. 2015. Pengaruh Profitabilitas, Pertumbuhan Penjualan, Struktur Aktiva, dan Ukuran Perusahaan Terhadap Struktur Modal. Jurnal Administrasi Bisnis, 28(1).

Oktaviani, G. L. \& Malelak, M. I. 2014. Analisa Pengaruh Profitabilitas, Pertumbuhan, Struktur Aktiva, dan Ukuran Perusahaan Terhadap Keputusan Struktur Modal Perusahaan. Jurnal Finesta, 2(2).

Pasopati, G. 2015,. CNN Indonesia. Dipetik Juni 13, 2017, dari CNN Indonesia: http:// www.cnnindonesia.com

Pertiwi, N. W. \& Artini, L. G. 2014. Pengaruh risiko bisnis, profitabilitas dan keputusan investasi terhadap struktur modal.E-Journal Manajemen Unud, 3(8),pp. 2456-2470.

Primantara, A. N., \& Dewi, M. R. 2016. Pengaruh Likuiditas, Profitabilitas, Risiko Bisnis, Ukuran Perusahaan dan Pajak Terhadap Struktur Modal. E-Jurnal Manajemen Universitas Udayana, 5(5).

Priyatno, D. 2010. Paham Analisa Statistik Data dengan SPSS. Jakarta: MediaKom.

Putri, M. E. 2012. Pengaruh Profitabilitas, Struktur Aktiva, dan Ukuran Perusahaan Terhadap Struktur Modal Pada Perusahaan Manufaktur Sektor Industri Makanan dan Minuman yang Terdaftar di BEI. Jurnal Manajemen, 1(1), pp. 1-10

Rinaldi, M. 2016,. BUMN Properti Anggarkan Belanja Modal Rp 2 Triliun di 2017. DipetikMei16,2017,dariLiputan6.com:http:// m.liputan6.com/bisnis/read/2663780/bumnpropertianggarkan-belanja-modal-rp-2-triliun-di2017

Riyanto, B. 2001. Dasar-dasar Pembelanjaan Perusahaan. Yogyakarta: BPFE.

Samryn, L. 2013. Akuntansi Manajemen: Informasi Biaya untuk Mengendalikan Aktivitas Operasi dan Informasi. Jakarta: Kencana.

Sartono, A. 2009. Manajemen Keuangan Teori dan Aplikasi. Dalam A. Sartono, Manajemen Keuangan Teori dan Aplikasi (hal. 225). Yogyakarta: BPFE-Yogyakarta.
Sartono, R. A. 2012. Manajemen Keuangan Teori dan Aplikasi. Yogyakarta: BPFE.

Sawitri, N. P. \& Lestari, P. V. 2015. Pengaruh Risiko Bisnis, Ukuran Perusahaan dan Pertumbuhan Penjualan Terhadap Struktur Modal. E-jurnal Manajemen Universitas Udayana, 4(5)

Siregar, I. 2017, PP Properti Right Issue 5 Miliar Lembar Saham. Dipetik Mei 16, 2017, dari metronews.com:

http://m.metronews.com/ekonomi/bursa/ 1bVYP1GN-pp-properti-right-issue-5-miliarlembar-saham

Sofiyuddin, M. 2015. Analisis Pengaruh Leverage Operasi, Pertumbuhan Aset dan Profitabilitas Terhadap Struktur Modal Studi Kasus pada Perusahaan Food and Beverages Yang Terdaftar di BEI. Jurnal Ekonomi dan Bisnis, 16(1).

Subramanyam, K. \& Wild, J. J. 2011. Analisis Laporan Keuangan. Jakarta: Salemba Empat.

Sudarmika, G. Y. \& Sudirman, M. S. 2015. Pengaruh Profitabilitas, Pertumbuhan Aktiva, Struktur Aktiva, dan Pajak Terhadap Struktur Modal . E-Jurnal Manajemen Universitas Udayana, 4(9).

Sukirno. 2016, Market Bisnis. Dipetik Maret 27, 2017, dari Market Bisnis: http://market. bisnis.com

Sukirno, S. 2002. Makroekonomi Teori Pengantar. Jakarta: PT. Rajagrafindo Persada.

Tambunan, P. 2015, Penjualan Properti Menurun di Tahun 2015. Dipetik November 18, 2017, dari usaha properti.com: http://www.usaha properti.com/penjualan-properti-menurun-ditahun-2015/

Umar, H. 2011. Metode Penelitian Untuk Skripsi dan Tesis Bisnis. Jakarta: PT RajaGrafindo Persada .

Utomo, L. L. 1999. Economic Value Added sebagai Ukuran Keberhasilan Kinerja Manajemen Perusahaan. Jurnal Akuntansi dan Keuangan, 1(1): 28 - 42.

Van Horne, J. C. \& Wachowicz, J. M. 2007. Prinsipprinsip Manajemen Keuangan. Jakarta: Salemba Empat.

Walsh, C. 2003. Key Management Ratios: Master the Management Metrics that Drive and Control Your Business. Pearson .

Wiagustini, N. L. \& Pertamawati, N. P. 2015. Pengaruh Risiko Bisnis dan Ukuran Perusahaan pada Struktur Modal dan Nilai Perusahaan pada 
Perusahaan Farmasi di Bursa Efek Indonesia. Jurnal Manajemen Strategi Bisnis dan Kewirausahaan. 9(2). pp. 112-122

Widayanti, L. P. Triaryati, N., \& Abundanti, N. 2016. Pengaruh Profitabilitas, Tingkat Pertumbuhan Perusahaan, Likuiditas dan Pajak Terhadap Struktur Modal. E-Jurnal Manajemen Unud, $5(6)$.

Wijaya, C. A. 2014. Pengaruh Struktur Aktiva, Profitabilitas, Pertumbuhan Penjualan,
Kebijakan Deviden dan Resiko Bisnis Terhadap Struktur Modal pada Perusahaan Food And Beverages yang terdaftar di BEI periode 20102012. Jurnal Online Mahasiswa Bidang Ilmu Ekonomi.

Winarno,W.W. 2009. Analisis Ekonometrika dan Statistika dengan Eviews. Yogyakarta: UPP STIMYKPN. 